PNL-SA- -20526

DE92 $\cap 15617$

\title{
INNOVATIVE TECHNOLOGY DEMONSTRATIONS
}

\author{
D. B. Anderson \\ J. N. Hart ley \\ S. P. Luttrell
}

April 1992

Presented at the

Waste Management and Environmental Restoration Apri 1 9-11, 1992

San Juan, Puerto Rico

Work supported by

the U.S. Department of Energy

under Contract DE-AC06-76RLO 1830

Pacific Northwest Laboratory

Richland, Washington 99352

\section{DISCLAIMER}

This report was prepared as an account of work sponsored by an agency of the United States Government. Neither the United States Government nor any agency thereof, nor any of their employees, makes any warranty, express or implied, or assumes any legal liability or responsibility for the accuracy, completeness, or usefulness of any informaticn, apparatus, product, or process disclosed, or represents that its use would not infringe privately owned rights. Reference herein to any specific commercial product, process, or service by trade name, trademark, manufacturer, or otherwise does not necessarily constitute or imply its endorsement, recommendation, or favoring by the United States Government or any agency thereof. The views and opinions of authors expressed herein do not necessarily state or reflect those of the United States Government or any agency thereof.

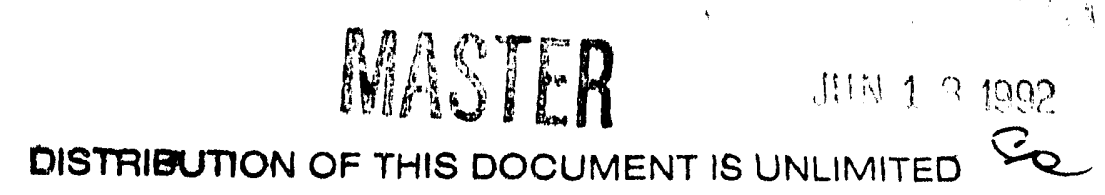




\title{
INNOVATIVE TECHNOLOGY DEMONSTRATIONS
}

\author{
Daniel B. Anderson ${ }^{1}$, James N. Hartley ${ }^{2}$ and Stuart P. Luttrell ${ }^{1}$
}

\section{SUMMARY}

Currently, several innovative technologies are being demonstrated at Tinker Air Force Base (TAFB) to address specific problems associated with remediating two contaminated test sites at the base. Cone penetrometer testing (CPT) is a form of testing that can rapidly characterize a site. This technology was selected to evaluate its applicability in the tight clay soils and consolidated sandstone sediments found at TAFB. Directionally drilled horizontal wells have been successfully installed at the U.S. Department of Energy's (DOE) Savannah River Site to test new methods of in situ remediation of soils and ground water (Kaback et al. 1989). This emerging technology was selected as a method that may be effective in accessing contamination beneath Building 3001 without disrupting the mission of the building, and in enhancing the extraction of contamination both in ground water and in soil. A soil gas extraction (SGE) demonstration, also known as soil vapor extraction, will evaluate the effectiveness of SGE in remediating fuels and TCE contamination contained in the tight clay soil formations surrounding the abandoned underground fuel storage vault located at the SW Tanks Site. In situ sensors have recently received much acclaim as a technology that can be effective in remediating hazardous waste sites. Sensors can he useful for determining real-time, in situ contaminant concentrations during the remediation process for performance monitoring and in providing feedback for controlling the remediation process. A demonstration of two in situ sensor systems capable of providing real-time data on contamination levels will be conducted and evaluated concurrently with the SGE demonstration activities. Following the SGE demonstration, the SGE system and SW Tanks test site will be modified to demonstrate bioremediation as an effective means of degrading the remaining contaminants in situ. The bioremediation demonstration will evaluate a bioventing process in which the naturally occurring consortium of soil bacteria will be stimulated to aerobically degrade soil contaminants, including fuel and TCE, in situ.

\section{INTRODUCTION}

The Innovative Technology Demonstration (ITD) program at Tinker Air Force Base (TAFB), Oklahoma City, Oklahoma, will demonstrate the overall utility and effectiveness of innovative technologies for site characterization, monitoring, and remediation of selected contaminated test sites. The current demonstration test sites include a CERCLA site on the NPL list, located under a building (Building 3001) that houses a large active industrial complex used for rebuilding military aircraft, and a site beneath and surrounding an abandoned underground tank vault used for storage of jet fuels and solvents. The site under Building 3001 (the NW Test Site) is contaminated with $\mathrm{TCE}$ and $\mathrm{Cr}^{+6}$; the site with the fuel storage vault (the SW Tanks Site) is contaminated with fuels, BTEX and TCE. These sites and others have been identified for cleanup under the Air Force's Installation Restoration. Program (IRP).

ithe following sections describe the demonstrations that have been conducted or are planned for the TAFB.

\section{DEMONSTRATION STRATEGX}

Three primary considerations related to planning and developing successful technology demonstration programs include 1) selecting technologies that have the potential to reduce cost, increase performance, and

\footnotetext{
${ }^{1}$ Pacific Northwest Laboratory, P.O. Box 999, Richland, WA 99352.

${ }^{2}$ Battelle Environmental Management Operations, 723 The Parkway, Richland, WA 99352.
} 
reduce risk; 2) working closely with the regulatory agencies to gain regulatory and public acceptauce; and 3) gathering field data on engineering applications related to cost performance, quality and reliability, and the schedule for implementation.

The general approach developed for the ITD program at TAFB has proven to be a good strategy for demonstrating and evaluating individual technologies in an integrated approach. The process begins with the selection of the test sites, followed by characterization of the test site(s) to understand the extent and distribution of the contaminants, geology, and hydrology, and to establish baseline levels of the contamination before starting the demonstrations. Based on the site characterization data and a more thorough understanding of the technical issues associated with remediating the selected test site(s), the specific technical approach and/or technologies are selected for implementation. Evaluation criteria are developec to ensure that the right data are collected throughout the demonstration in order to thoroughly evaluate the performance of the technology in the field. The technologies are then implemented at the test site and operated for an appropriate period of time to adequately evaluate performance. Data collected are evaluated against the selected evaluation criteria and a determination of the overall effectiveness of the technology is made. In addition, the potential for implementation and the reliability of the technologies are monitored and evaluated. Another important result from conducting these demonstration activities is that often the test site can be partially or, in some cases, completely remediated during the course of the demonstration. In most cases a suitable design may be developed for completing the remediation activities for sites containing the demonstration test sites.

\section{SITE SELECTION AND CHARACTERIZATION}

\section{Site Selection}

The NW Test Site is located beneath Building 3001 in the vicinity of a number of abandoned solvent pits. This site was selected because data obtained during previous investigations revealed that the unsaturated sediment near one abandoned pit was contaminated with TCE (the major contaminant), and ground water was contaminated primarily with TCE and chromium. It was believed that this site would provide an ideal setting in which to install horizontal wells beneath the building and evaluate their ability to access contamination in both the saturated and unsaturated zone, and thus demonstrate the applicability of horizontal wells for remediation of this and similar sites.

The SW Tanks Site is located in the vicinity of several abandoned fuel taaks that contained primarily fuel products. Previous investigations revealed that the ground water was contaminated primarily with BTEX. It was believed that the unsaturated sediment also may be contaminated with similar products. It was believed that this site would provide an ideal setting in which to conduct and evaluate soil gas extraction in tight soil.

The SW Tanks Site and the NW Test Site were toth originally selected originally to evaluate in situ sensor systems for BTEX and TCE, respectively. Subsequently, TCE contamination was also discovered at the SW Tanks Site, so it was decided to consolidate the in situ sensor demonstrations at that site and integrate the sensor demonstration with the SGE demonstration. This integrated approach will permit evaluation of the sensor systems in an actual re: nediation process.

\section{Approach to Site Characterization}

To perform a valuable demonstration of technology, each of the sites required specific characterization to meet two primary objectives: 1) to determine the geologic setting and hydrogeology of the sites; and 2) to determine the contaminant types, concentrations, and distribution at the sites. Site characterization was conducted at both sites by means of surface geophysics, borehole drilling and sediment sampling, soil gas monitoring probe installation and sampling, monitoring well installation and sampling, and sample analysis. 
CPT was attempted; however, it could not penetrate the sandstone that underlies both sites at a depth of approximately $10 \mathrm{ft}$.

Surface geophysical surveys were conducted at both sites to locate underground utilities and structures. Borehole drilling and sampling was conducted with an auger drilling rig. Twelve boreholes were drilled at the NW Test Site, ranging from a depth of approximately $25 \mathrm{ft}$ to approximately $38 \mathrm{ft}$ below the floor of Building 3001 . Approximately 20 boreholes were drilled at the SW Tanks Site, ranging from a depth of approximately $20 \mathrm{ft}$ to approximately $40 \mathrm{ft}$ below land surface. Most of these boreholes are 20 - $\mathrm{ft}$ deep. Both ground-water monitoring wells and unsaturated-zone soil-gas monitoring wells were installed in most of the boreholes.

Sediment samples for analysis were obtained within a 5 -ft core barrel and then subsamples were placed into jars for transport to a laboratory. Head-space analyses of sediment samples were conducted on site with a gas chromatugraph.

Soil-gas monitoring was conducted at the SW Tanks Site. Soil-gas monitoring points consisted of inlet probe tips attached to Teflon tubing extending to land surface. Twenty-six monitoring points were installed at depths ranging from approximately $3 \mathrm{ft}$ to approximately $16 \mathrm{ft}$. Soil gas was pumped from the monitoring points and measurements were made with a photoionization detector, oxygen meter, and carbon dioxide meter. Samples were collected and analyzed both by the on-site gas chromatograph and an off-site laboratory.

\section{Summary of Site Characterization Results}

NW Test Site. Drilling and geologic sampling at the NW Test Site indicated variable geologic conditions. The sediments consist of clay, silt, and sand, and gradations between these texture classes (e.g. silty sand), which are moderately consolidated in places. The sedimentary units cannot be well correlated beneath the site because of considerable lateral variability.

Ground water occurs generally in units of silty to fine sand at a depth ranging from approximately 19 to $26 \mathrm{ft}$ below the building floor. Because of the complex character of the sedimentary units, the ground-water level is not consistent beneath the site, and fluctuates significantly in response to precipitation.

Sediment sample analyses indicate solvent contamination, primarily in the upper $7.5 \mathrm{ft}$ of the soil column. Tetrachloroethylene was reported as high as 5.9 parts per million (ppm) at a depth interval of 4.5 to $5.0 \mathrm{ft}$ from one borehole; however, no other analyses indicated concentrations greater than $0.45 \mathrm{ppm}$ of this or any other contaminant. Dichloromethane, TCE, and 1,2-dichloroethane were also detected in sediment samples.

Soil gas analyses from vapor monitoring points and head-space analyses of sediment samples indicated very high levels of T'CE. The highest head-space concentrations were on the order of hundreds of $\mathrm{ppm}$, and the highest soil-gas concentrations were on the order of thousands of ppm.

SW Tanks Site. The sediments underlying the SW Tanks Site include sand, silt, and clay, and gradations between these texture classes (e.g., silty sand). The sediments are moderately consolidated in places. The sedimentary units are fairly continuous across the site and can be generally correlated.

Ground water occurs generally within the silty sand, and at a depth ranging from approximately 15 to $18 \mathrm{ft}$ below land surface. The water level fluctuates significantly in response to precipitation.

Soil contamination was believed to be encountered during excavation with a backhoe to locate the southwest corner of the tanks. The contamination was evidenced by odors, elevated readings with a field contamination detector, and sighting of suspected liquid contaminants. 
Sediment sample analyses indicate fuel product contamination from essentially land surface to below the water table (to a depth of $35 \mathrm{ft}$ ). The primary contaminant reported was total petroleum hydrocarbons (TPH), which was widespread beneath the site. The highest value reported was approximately $63,400 \mathrm{ppm}$ from a depth interval of 5 to $6.5 \mathrm{ft}$ from a borehole located near the tanks. Other contaminants reported include toluene, xylene, ethyl benzene, 1,4-dichlorobenzene and benzene (the latier two at very low levels). Chlorinated hydrocarbons, especially TCE, were noticeably absent from the sediment analyses.

Soil gas analyses from vapor-monitoring points and head-space analyses ? sediment samples indicated very high levels of toluene, benzene, and TCE. The highest head-space concentrations were on the order of hundreds of $\mathrm{ppm}$ for all three contaminants. The highest soil-gas concentrations were on the order of thousands of ppm for TCE and toluene (benzene was not detected). Soil-gas analyses also indicated depleted oxygen levels (less than 1\% in some locations) and increased carbon dioxide levels (greater than 5\% in some locations). The locations of decreased oxygen, increased carbon dioxide, and elevated contamination generally corresponded to one another.

\section{TECHNOLOGY DEMONSTRATIONS}

\section{Cone Penetrometer Testing}

The applicability of using CPT, as shown in Figure 1, was evaluated during site characterization. The original scope of CPT activities included use of CPT within Building 3001 (later removed from the scope of work), use of a variety of CPT instruments, and integration of CPT with conventional boring and sampling. The original approach was to use the CPT for field chemistry screening and initial stratigraphy delineatiun. The CPT would be used to augment sediment boring/sampling for detailed site characterization. The data obtained with CPT would also be compared to data obtained by boring/sampling. It was realized from the onset that the geologic materials may be too hard for the CPT to penetrate, a potential limitation to the use of this technology.

Several companies with capabilities to perform CPT were contacted and their capabilities reviewed. Technical requirements for the company that provided CPT services included: 1) standard tip resistance/sleeve friction to determine stratigraphy, 2) soil gas sampling, 3) sediment sampling, 4) water sampling, 5) geophysical logging, 6) capability to install small-diameter piezometers, 7) ability to grout all holes, and 8) a minimum 20-ton thrust capacity.

The contractor selected was not able to push the cone into the sandstone beneath either sites. The sandstone lies at a depth of approximately $11 \mathrm{ft}$. However, above that depth the CPT rig demonstrated capability to determine the stratigraphy, to obtain sediment samples, to obtain soil gas samples, and to perform natural gamma logging. Although the CPT was not effective in assisting characterization at these locations, its use as a site characterization tool cannot be ruled out at other locations where the sediments are not consolidated.

\section{Horizontal Drilling and Wells}

The approach taken for demonstrating horizontal drilling and well installation was to install a minimum of one and a maximum of three horizontal wells beneath Building 3001 . The success of the first installation would establish whether a second and third well would be installed. The location for the wells was planned to be approximately $200 \mathrm{ft}$ west of the building. The first well was planned to be installed several feet below the water table, and the second and third wells a few feet above the water table. The wells would then be evaluated for their application in remediating the site.

Each borehole and well installed had to meet the following requirements: 1) the borehole had to be drilled up to $350 \mathrm{ft}$ in horizontal distance from the point of surface entry, 2) borehole drilling control and accuracy 


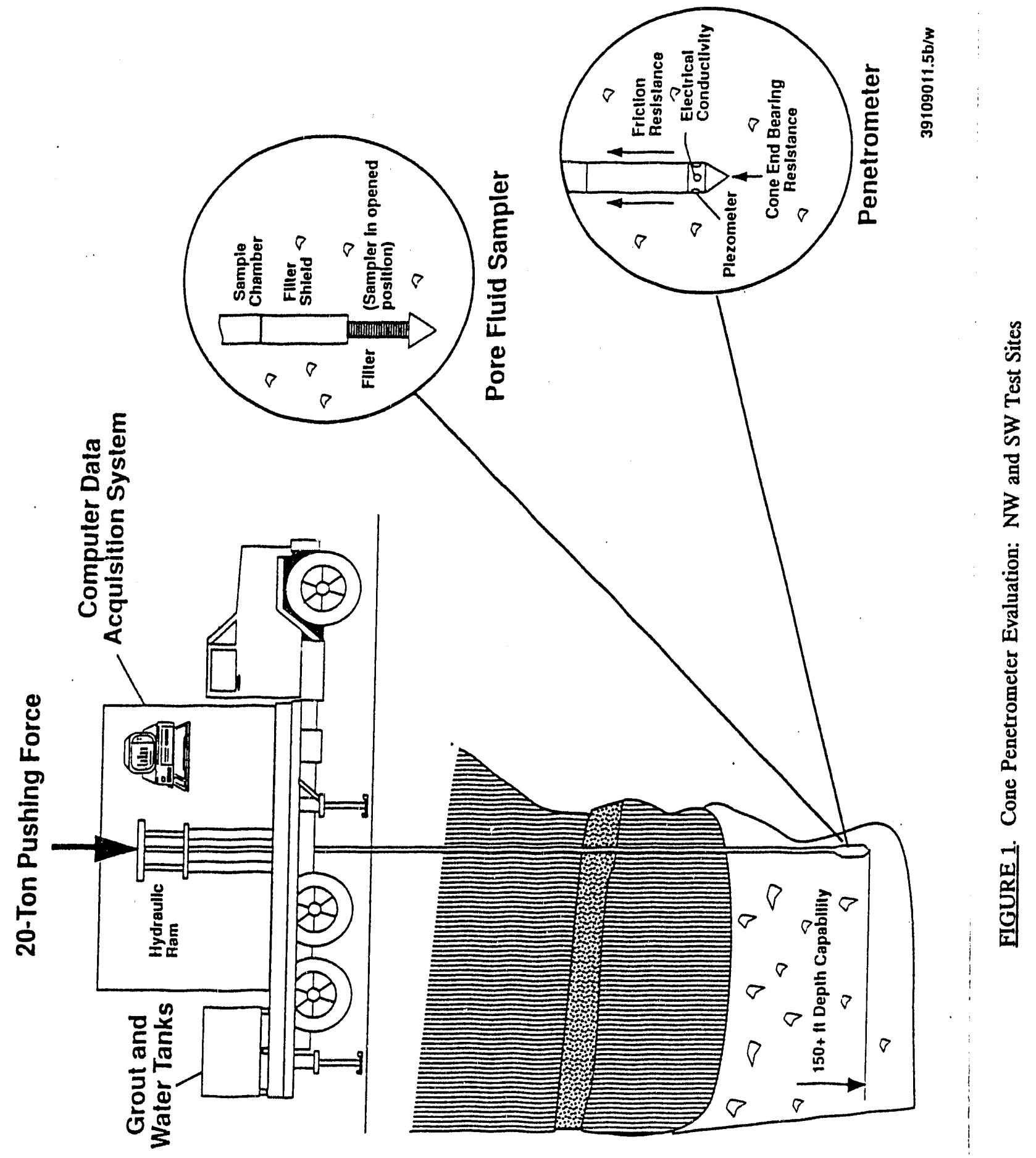


had to permit interception of a predetermined location (vertical and horizontal control had to be maintained the entire length of the borehole so that obstacles would not be encountered), 3) a 6-in. casing and preslotted screen had to be installed to the full length of each borehole, 4) a cement grout surface seal had to be installed, 5) the well had to be integrity tested and developed, and 6) a directional survey had to be conducted to ascertain the specific location of the completed well.

Evaluation criteria were established before beginning field activities and were documented in a work plan. The evaluation criteria for well installation included 1) hole location - the final location of each hole had to be determined to within plus or minus $1 \mathrm{ft}, 2$ ) well completion - acceptable completion required no compromise of the screen and casing integrity during completion, and 3) well development - proper movement of fluid or gas from the formation into the well had to be ensured.

Two horizontal wells were successfully installed beneath Building 3001 at the NW Test Site. A directionally controlled downhole drill motor was used with a mud rotary fluid circulation system. A deviation probe was situated within the drill rod behind the drill motor to ascertain both the inclination and azimuth of the borehole, and to control the orientation of the drill motor. A magnetic locating system (the sensor was located in the drill rods behind the drill motor) was also used to more precisely locate the oorehole. Information from this tracking system was then relayed to the driller to make steering adjustments. This dual-tracking system proved to be invaluable in tracking and controlling the location of the pilot hole. The pilot hole was reamed to a diameter of $6 \mathrm{in}$. and then $9 \mathrm{in}$. before the casing and screen were installed. Both wells were completed with 6-in.-dia. PVC casing and $75 \mathrm{ft}$ of 6-in. pre-pack 10-slot screen installed horizontally. The first well was installed at a depth of approximately $24 \mathrm{ft}$. The length of screen and casing in this well totalled $285 \mathrm{ft}$. The magnetic tracking system indicated the location $0.5-\mathrm{ft}$ above and $2.4-\mathrm{ft}$ right of the target location. The second well was installed at a depth of approximately $14 \mathrm{ft}$, and the length of screen and casing of this well totalled approximately $276 \mathrm{ft}$. The magnetic tracking system indicated the location 0.5 - $\mathrm{ft}$ below and 0.3 - $\mathrm{ft}$ right of the target.

The installation of these wells was considered to be successful because the evaluation criteria were met. Figure 2 shows the completed wells and the configuration that will be used in the next phase of this demonstration to evaluate the performance of each well. This work will include an extended ground-water pump test in which the yield, draw down and zone of influence will be determined for potential use in pump and treatment of the ground-water plume. There will also be an evaluation of the well in the unsaturated zone in which soil gas will be extracted to determine the zone of influence and rate of contaminant removal that can be achieved using horizontal wells. This evaluation will be important for future design considerations in accessing sources of contamination located in the unsaturated zone beneath Building 3001.

\section{Soil Gas Extraction}

An SGE demonstration will be conducted at the SW Tanks Site using vertical extraction wells to evaluate this method for remediation of the contaminated soils around the tank vault. This SGE demonstration involves the vapor extraction of fuel components and TCE contained in the unsaturated zone, integrated with a groundwater extraction system for depression of the water table to expose more of the contaminated soil for vapor extraction and a free product recovery system. Two soil gas extraction cluster wells will be installed. Each of these cluster wells will be capable of extracting ground water, free product, and soil gas from at least two depth discrete zones. A series of tri-level soil gas monitoring points will be installed radially around the cluster wells to monitor soil gas pressure (flow) and soil gas chemistry. The demonstration will evaluate at least nine different operation configurations for SGE using the combined capabilities of the two extraction cluster wells for testing combinations of vacuum extraction with pressurized injection, and passive venting across the two cluster well systems.

Although SGE is not an innovative or new technology for remediating fuel- or TCE-contaminated sites, the application of this technology to the tight clay-shale-sandstone sediments and stratigraphy found at this site 


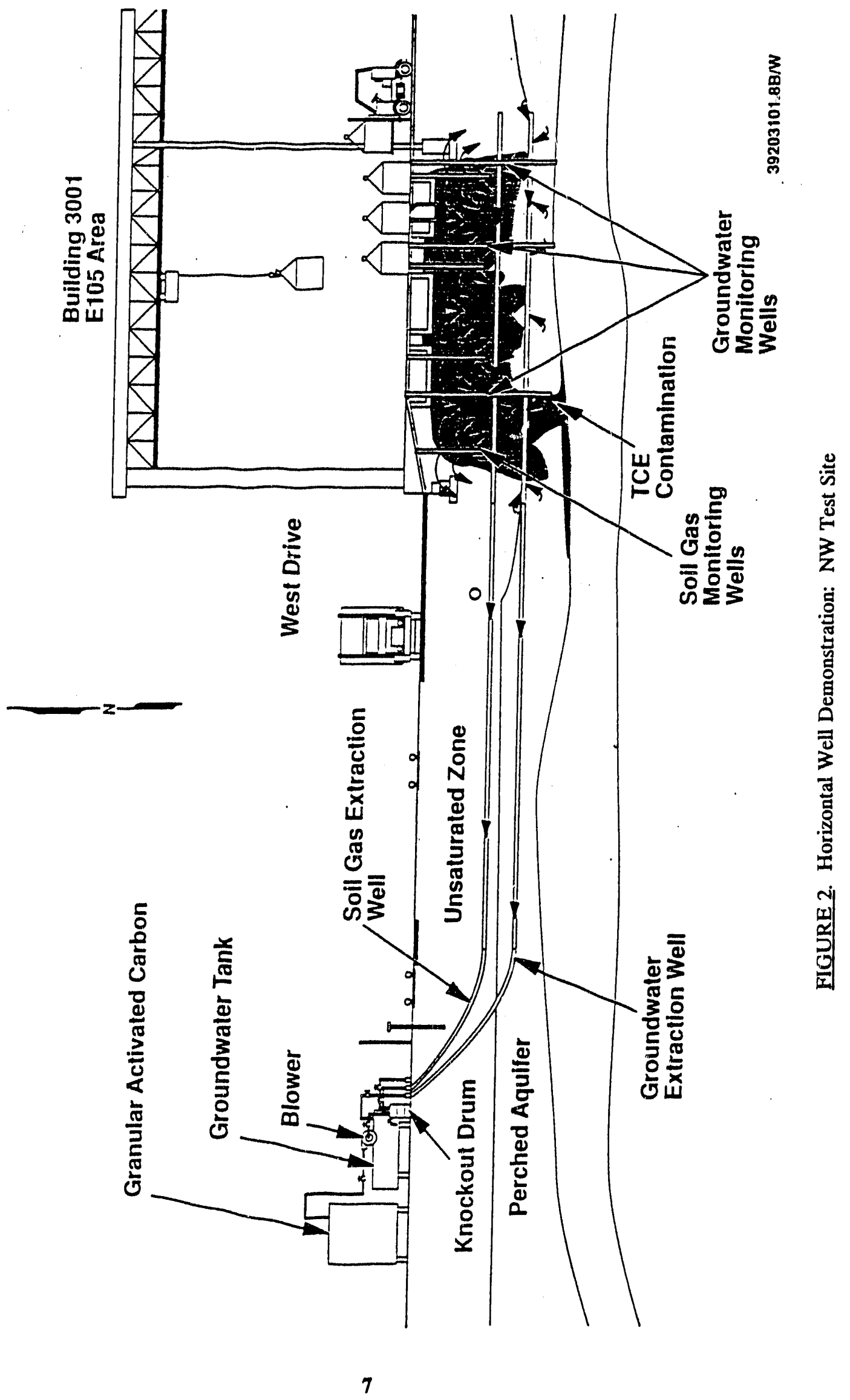


will require innovative applications. The evaluation criteria are based on practical data requirements that are needed in designing, operating and monitoring an SGE system (Johnson et al. 1990). Evaluation criteria for the SGE demonstration include:

- soil gas permeability (determining maximum vapor flow rates)

- vapor flow path (ability to monitor and influence vapor flow)

- contaminant vapor concentrations (removal rates)

- residual soil contamination.

Once the best operating configuration has been determined, the system will be operated in that mode for up to 4 months. Figure 3 shows a conceptual design of the SGE demonstration integrated with the in situ sensors.

\section{In Situ Sensors}

In situ sensors may have valuable applications for remediation work at the Tinker Air Force Logistics Center and at other locations. Two different in situ sensors will be demonstrated and evaluated at the SW Tanks Site. Because both BTEX and TCE were identified during site characterization, sensors with the ability to quantify both of these contaminants will be demonstrated. The sensors will be used during a soil gas extraction (SGE) test that will be conducted at the site, and the will be evaluated for general and specific applications to remediation.

The BTEX sensor selected for the demonstration is marketed by FCI-FiberChem, Inc. (FCI) under the name Petrosense. The TCE sensor selected was recently developed by Pacific Northwest Laboratory. The Halo Snif system, as it is called, is a chlorinated hydrocarbon sensor. The sensor is not truly capable of ira situ measurements-with the current design, a gas sample must be drawn from the source to the sensor.

The evaluation criteria for sensor demonstration include:

- usability (ease of installation, ease of use, and durability)

- sensitivity (ability to discriminate between different contamination concentrations)

- minimum detection limit (minimum measurable contaminant concentration)

- specificity (ability to discriminate between different contaminants)

- reproducibility (ability to reproduce measurement of contaminants of equal concentration)

- accuracy

- precision

- dynamic range.

Soil gas monitoring wells will be installed and instrumented with the sensors or with tubing that leads the sensors, which will be operated during the SGE test. Gas samples will also be collected from the monitoing wells for analysis with an on-site gas chromatograph. Results from these analyses will be used for comparison with the data collected with the sensors. The sensors will be operated for some period of time before the SGE test, during the SGE test (which will last up to four months), and after the SGE test.

\section{Bioremediation}

Following the SGE demonstration, this same test site will be used to demonstrate a bioremediation process called "bioventing," a process in which native soil bacteria are stimulated to aerobically degrade the contaminants in situ (Hoepel et al. 1991). Air flow levels used for SGE will be lowered such that the unsaturated zone can be maintained in an aerobic state, and the level of contaminants extracted in the vapor phase will be greatly diminished. The bioremediation demonstration includes biotreatabilty studies to determine the degradation kinetics; potential limiting factors such as temperature, moisture and nutrients; 


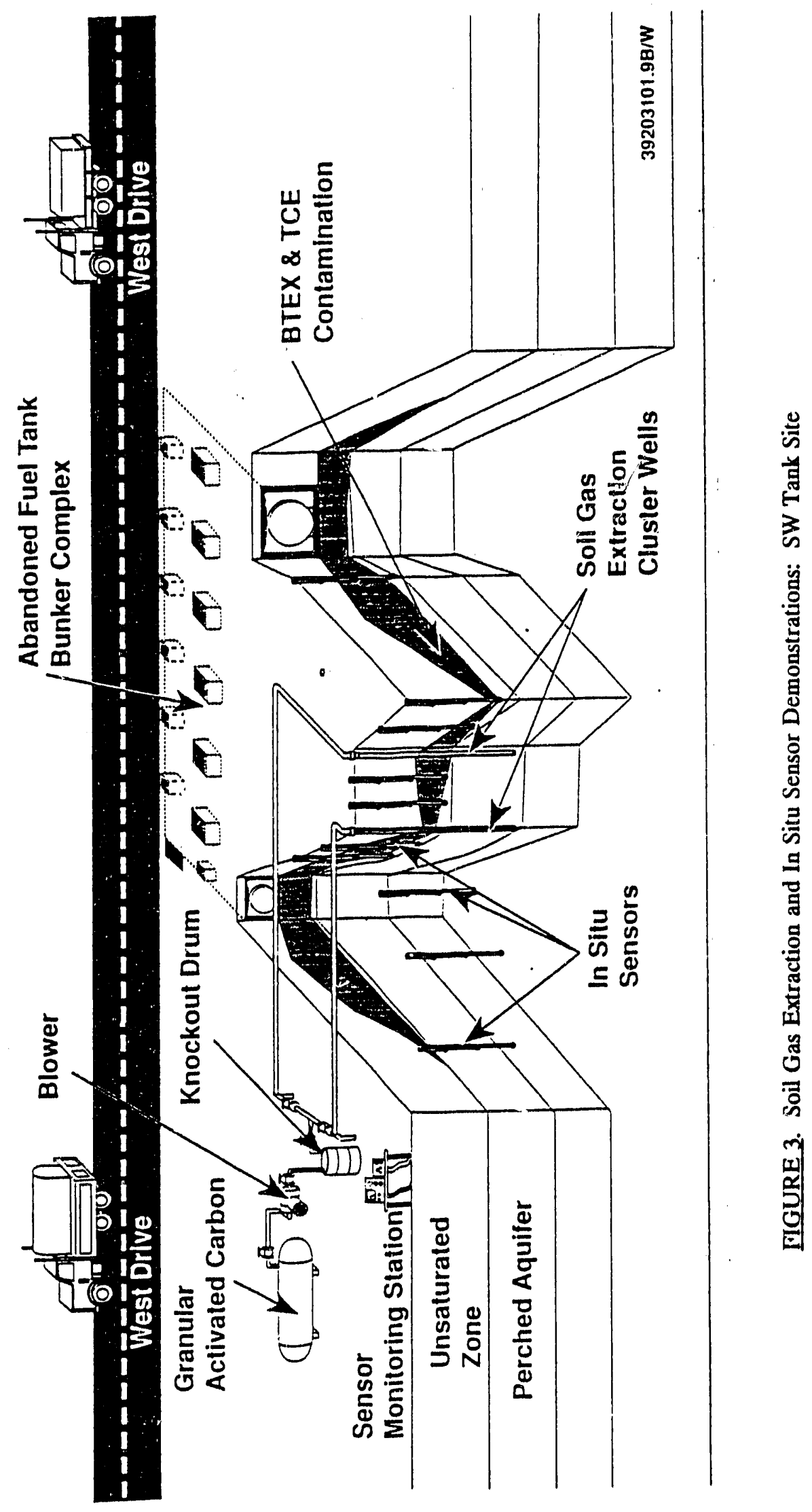


and the methods to stimulate the degradation of TCE by co-metabolic processes. An initial field treatability survey has been completed for in situ respiration testing. In these tests, selected zones of contaminated soil are injected with air to create an aerobic environment. After air injection is complete, the levels of oxygen, carbon dioxide, and total petroleum hydrocarbons (TPH) are monitored. The decrease in oxygen over time corresponds to the rate of biological degradation of the fuel contaminants. Estimated biodegradation rates from the initial survey ranged from 2.7 to $18 \mathrm{mg} /(\mathrm{Kg}$-day). These compare favorably to biodegradation rates at other sites where bioventing has been shown to be an effective remediation technology. Results from the biotreatabilty studies and the in situ respiration tests will be used to design and operate the bioremediation demonstration.

\section{CONCLUSIONS}

These demonstrations at TAFB will provide data needed to evaluate the potential for innovative remediation technologies that could be incorporated into the current and future remedial actions at TAFB and other similar hazardous waste sites at military installations across the country. Identifying appropriate technologies and demonstrating them in the field at actual hazardous waste sites provides the true test of the overall effectiveness and performance of a new remediation technology. If a technology is demonstrated to be effective under actual field conditions, then that technology has great potential for reducing the time, costs, and risks associated with remediation of specific hazardous waste sites.

\section{ACKNOWLEDGMENT}

Pacific Northwest Laboratory is operated by Battelle Memorial Institute for the U.S. Department of Energy under Contract DE-ACO6-76RLO 1830.

\section{REFERENCES}

Kaback, D.S., B.B. Looney, J.C. Corey, L.M. Wright, III, and J.L. Steele. 1989. "Horizontal Wells for InSitu Remediation of Groundwater and Soils." Proceedings of the Third National Outdoor Action Conference on Aquifer Restoration, Groundwater Monitoring, and Geophysical Methods, Association of Ground Water Scientists and Engineers, pp. 121-135.

Johnson P.C., C.C. Stanley, M.W. Kemblowski, D.L. Byers, and J.D. Colthart. 1990. "A Practical Approach to the Design, Operation, and Monitoring of In Situ Soil-Venting Systems." Ground Water Monitoring Review, Spring 1990, pp. 159-178.

Hoepel, R.E., R.E. Hinchee, and M.F. Arthur. 1991. "Bioventing Soils Contaminated With Petroleum Hydrocarbons." Journal of Industrial Microbiology, 8:141-146. 
$\therefore$
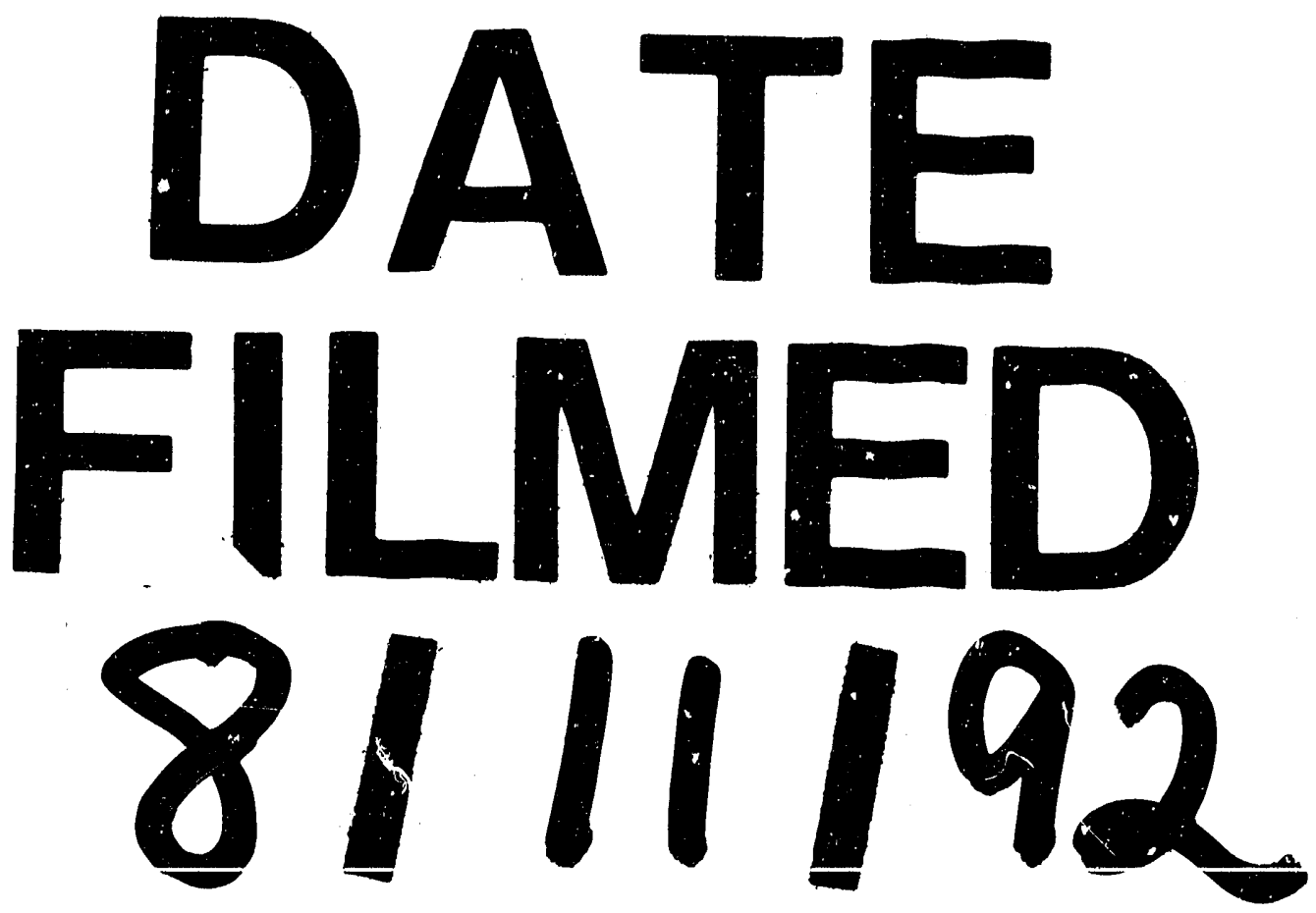

$\overline{\bar{n}}$ 